\title{
Perancangan Aplikasi Smart Indicator Lecturer Berbasis Android Menggunakan Microcontroller
}

\author{
Mohamad Dimas Radityatama ${ }^{\# 1}$, Fauziah $^{\# 2}$, Nur Hayati ${ }^{\# 3}$

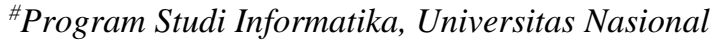 \\ Jl. Sawo Manila, Pejaten, Ps. Minggu, Jakarta 12520 \\ ${ }^{1}$ mdimasradityatamalgmail.com \\ ${ }^{2}$ fauziah@civitas.unas.ac.id \\ ${ }^{3}$ nurhayati@civitas.unas.ac.id
}

\begin{abstract}
Abstrak- Berdasarkan Google I/O 2019, pengguna Android telah meningkat 500 juta pengguna sejak dua tahun lalu. Disisi lain, kehadiran dosen di Universitas masih belum bisa dipantau secara realtime sebab hanya menggunakan papan geser manual jika dosen telah sampai ditujuan dan papan tersebut hanya dapat dilihat jika kita berada di Universitas, contohnya yang berada di Fakultas Teknologi Komunikasi dan Informasi Universitas Nasional, dengan memanfaatkan pesatnya perkembangan smartphone berbasis Android, maka dapat dibuat aplikasi Indikator informasi dosen berbasis Android. Berdasarkan penelitian terdahulu pemanfaatan Microcontroller menggunakan fingerprint sebagai media absensi dinilai efisien. Penelitian ini menggunakan Microcontroller untuk perancangan smart indicator lecturer berbasis Android dengan menggunakan fingerprint dosen. Aplikasi dirancang dengan menggunakan modul fingerprint R307 dan NodeMCU yang akan di kirim pada database firebase dan akan mengubah indicator kehadiran dosen pada smartphone. Berdasarkan hasil pengujian didapat rata - rata keberhasilan fingerprint sebesar $88,6 \%$ dan rata - rata $87 \%$ user menyatakan sangat setuju bahwa aplikasi mudah dipahami dan dioperasikan.
\end{abstract}

Kata kunci- Android, Fingerprint, Lecturer, Microcontroller, Absensi.

\section{Pendahuluan}

Pada Google I/O 2019, pengguna Android meningkat 500 juta pengguna sejak dua tahun lalu yang telah mencapai total 2 miliar pengguna [1]. Disisi lain kehadiran dosen di Universitas masih belum bisa dipantau secara realtime sebab hanya menggunakan papan geser manual jika dosen telah sampai ditujuan dan papan tersebut hanya dapat dilihat jika kita berada di Universitas, contohnya yang berada di Fakultas Teknologi Komunikasi dan Informasi Universitas Nasional. Berdasarkan permasalahan yang ada, memanfaatkan perkembangan Android sebagai media perantara berupa aplikasi dinilai lebih fleksibel sebab sifat smartphone yang memiliki mobilitas tinggi, maka akan dirancang aplikasi untuk memantau kehadiran dosen berbasis Android agar mahasiswa dapat melihat kehadiran dosen dengan memanfaatkan aplikasi yang dirancang.

Penelitian yang dilakukan Rahayu Purwanti, Fathan dan Senja mengenai respon fingerprint dideteksi menghasilkan rata-rata waktu 43.6 second, sebagai waktu sampling untuk mengenali pola sidik jari pada sistem presensi [2]. Penelitian yang dilakukan Salita dan Handoko dengan menggunakan fingerprint berbasis Mikrocontroller menghasilkan pengujian untuk mengetahui persentase tingkat keakuratan sistem untuk record fingerprint yaitu sebesar $86,67 \%$ dengan skenario pengujian adalah proses pendaftaran (record) sebanyak 6 kali untuk 10 fingerprint yang berbeda [3]. Penelitian yang dilakukan Baiq Rizki, Arimbawa dan Fitri dengan mengimplementasikan IoT menggunaka sensor fingerprint menghasilkan nilai waktu tersingkat 1,036 detik dan waktu terlama 1,408 detik dengan waktu rata-rata yang didapatkan sebesar 1,1241 detik [4].

Berdasarkan penelitian terdahulu, penerapan sensor fingerprint dinilai berhasil dan cepat dalam prosesnya, maka penelitian ini merancang smart indicator lecturer dengan Microcontroller berbasis Android menggunakan fingerprint dosen. 


\section{Metode Penelitian}

\section{A. Metode Perancangan Sistem}

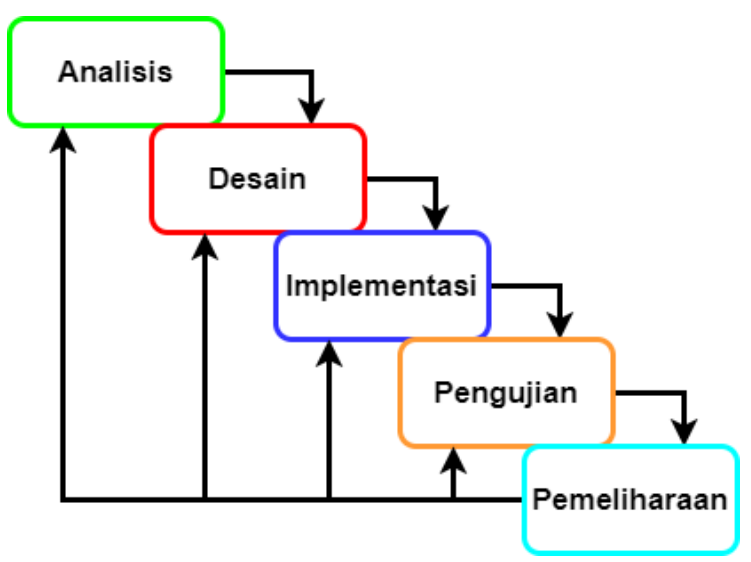

Gambar. 1 Metode waterfall

Pada perancangan aplikasi ini menggunakan metode waterfall dapat juga disebut metode air terjun. Metode ini terdapat 5 tahapan, yaitu:

1) Analisis : Tahapan ini adalah tahapan pertama pada metode waterfall untuk melakukan analisis pada sistem yang akan dirancang dengan detail. Pada tahapan ini menganalisis sistem secara keseluruhan baik dalam kebutuhan oleh pengguna dan batasannya mulai dari konsep prototype smart indicator lecturer, cara kerja sistem smart indicator lecturer, halangan yang akan muncul dalam melakukan perancangan smart indicator lecturer, tujuan yang dicapai serta kegunaan dan spesifikasi smart indicator lecturer.

2) Desain : Pada tahapan ini kelanjutan dari tahapan sebelumnya yang sudah melakukan analisis apa saja yang dibutuhkan. Maka tahapan ini akan menentukan spesifikasi yang lebih rinci dari tahapan analisis. Pada penelitian ini dibuat aplikasi smart indicator lecturer perangkat lunak berbasis android untuk monitoring dan perangkat keras berbasis microcontroller.

3) Implementasi : Pada tahapan ini akan melakukan penerapan keseluruhan yang sudah disiapkan pada tahapan sebelumnya dimana desain sistem akan diubah menjadi program yang sesuai dengan kesepakatan sebelumnya. Program untuk perangkat lunak maupun program untuk perangkat kerasnya. Selanjutnya bagian uji sistem akan melakukan verifikasi apakah sistem sudah sesuai dengan keperluan atau tidak.

4) Pengujian : Pada tahapan ini melanjutkan sistem yang sudah dibuat pada tahap implementasi untuk mengintegrasikan dan diuji untuk mengetahui kesesuaian sistem yang telah dirancang sebelumnya.

5) Pemeliharaan : Ini adalah tahapan akhir dalam metode waterfall dimana sistem akan dijalankan serta dilakukan pemeliharaan guna memperbaiki kesalan sistem jika ada kesalahan sistem yang tidak ditemukan sebelumnya.

\section{B. Analisis Kebutuhan Sistem}

Dalam tahapan analisis kebutuhan sistem bertujuan untuk mengidentifikasi kebutuhan apa saja yang dibutuhkan dalam merancang sistem yang akan dibuat [5]. Didapatkan kebutuhan sistem perangkat lunak (software) dan perangkat keras (Hardware).

- Kebutuhan Software: Atom v1.40.1, Arduino IDE v1.8.10, Android Studio v3.4.2, draw.io, Fritzing,

- Kebutuhan Hardware: NodeMCU ESP8266 WiFi, Fingerprint R307, Smartphone Android.

\section{Perancangan Perangkat Keras}

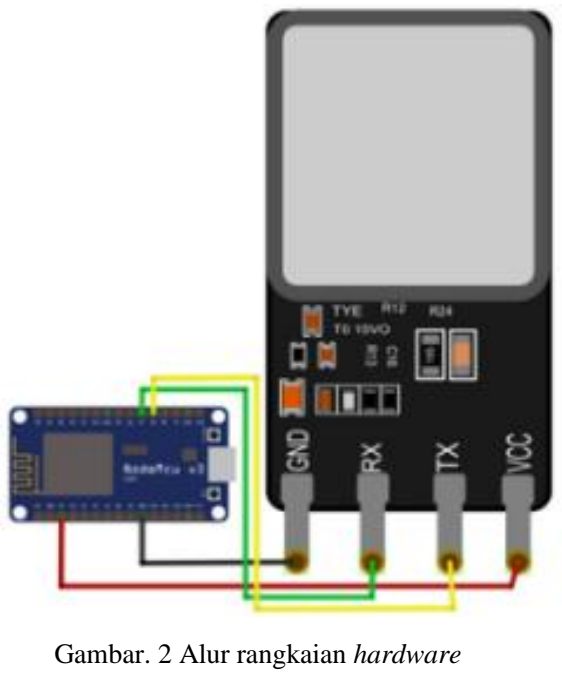

Pada perancangan hardware pada Gambar 2 terdiri dari:

- 1 NodeMCU ESP8266

- 1 Fingerprint R307

D. Blok Diagram Rangkaian

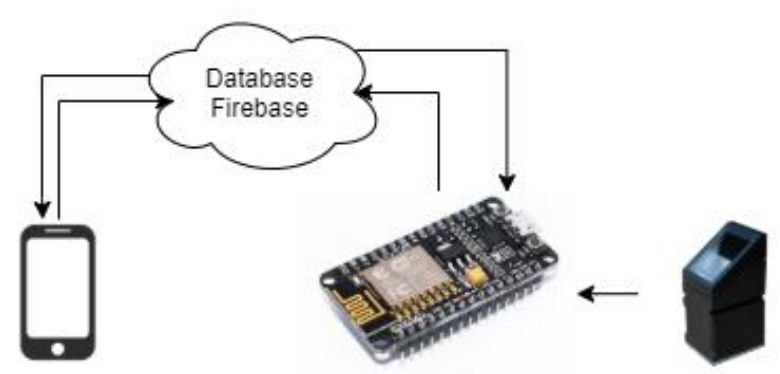

Gambar. 3 Diagram blok sistem

Perancangan blok diagram bertujuan untuk merealisasikan sistem agar mudah dipahami [6]. Alur dalam blok diagram dimulai dari dosen scan fingerprint pada sensor fingerprint selanjutnya Microcontroller akan melakukan pengecekan status kehadiran. Microcontroller akan melakukan perubahan status kehadiran dosen. Semua data dikirim ke dalam database Firebase [7]. Pada Microcontroller akan mendapatkan informasi dari database bahwa status kehadiran dosen berubah sesuai dengan tindakan yang dilakukan. Selanjutnya Android akan mengikuti database Firebase untuk merubah 
keterangan dosen sesuai dengan kehadiran dosen yang dikirimkan oleh Microcontroller ke database Firebase [8].

\section{E. Flowchart Sistem}

Flowchart digunakan untuk melihat instruksi terperinci dari setiap proses pada sistem yang dirancang.

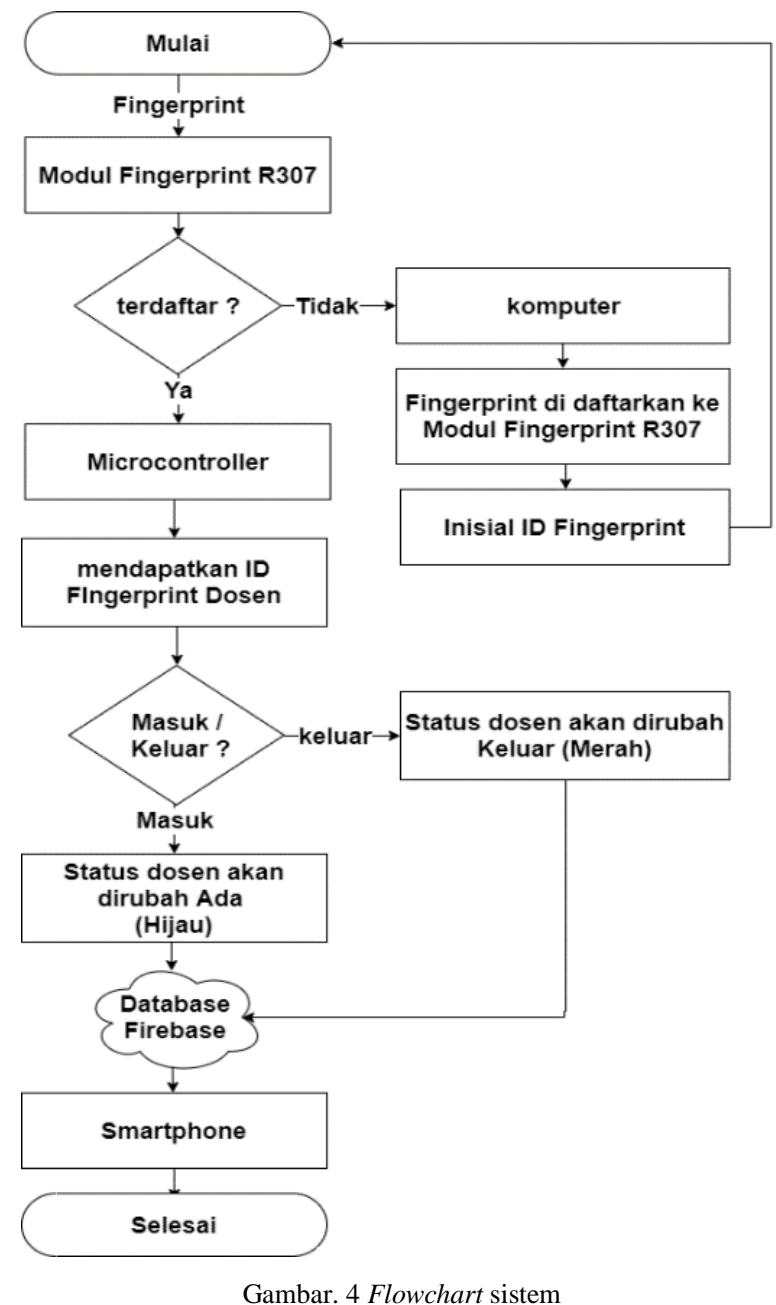

Pada Gambar. 4 diketahui alur proses penelitian dari awal persiapan modul fingerprint R307 sampai dengan mendapatkan identitas fingerprint kemudian pada smartphone mengalami perubahan seiring kehadiran dosen [9].

1. Persiapan Modul Fingerprint R307.

2. Menghubungkan Modul Fingerprint R307 terhadap komputer untuk persiapan memasukan data fingerprint

3. Scan fingerprint dan pemberian ID pada fingerprint.

4. Rangkaian yang sebelumnya dihubungkan ke computer, sekarang dipindahkan ke rangkaian Microcontroller.

5. Perangkat disiapkan untuk scan.
6. Dosen melakukan scan pada fingerprint yang kemudian akan dilakukan proses selanjutnya pada Microcontroller.

7. ID yang didapatkan kemudian akan dikirimkan pada database Firebase.

8. Smartphone akan mengetahui dosen tersebut telah hadir atau keluar ketika Firebase ada perubahan yang terjadi.

\section{HASIL DAN PEMBAHASAN}

\section{A. Swimlane Diagram}

Berdasarkan rancangan sistem yang ada, maka dihasilkan swimlane diagram yang menggambarkan interaksi pada setiap subset dari sebuah proses [10].

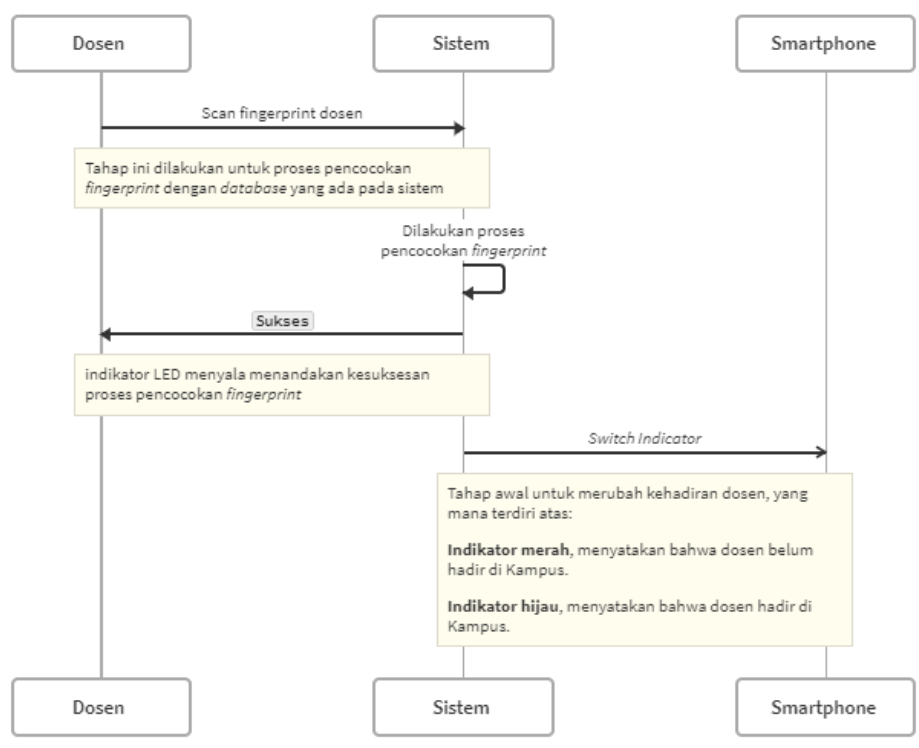

Gambar. 5 Swimlane diagram

Gambar 5 menjelaskan proses dari interaksi disetiap bagian, yang mana dimulai dari dosen melakukan scanning fingerprint, kemudian sistem akan mencocokan dengan database dan jika dinyatakan cocok maka akan muncul notifikasi kesuksesan dari indikator LED yang menyala, kemudian sistem akan meneruskan notifikasi kehadiran dosen dengan mengubah lampu indikator yang ada pada aplikasi android yang dirancang [11]. 


\section{B. Tampilan Aplikasi}

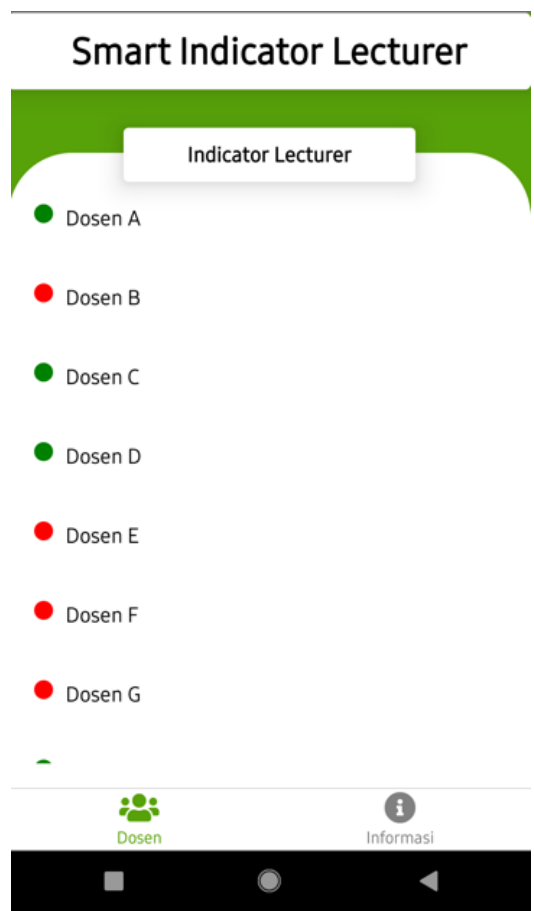

Gambar. 6 Tampilan indikator kehadiran dosen

Pada Gambar 6 menampilkan keterangan perihal kehadiran dosen yang telah melakukan absensi di Universitas, dengan indikator warna hijau yang menandakan hadir dan indikator warna merah yang menandakan ketidakhadiran dosen di tempat [12].
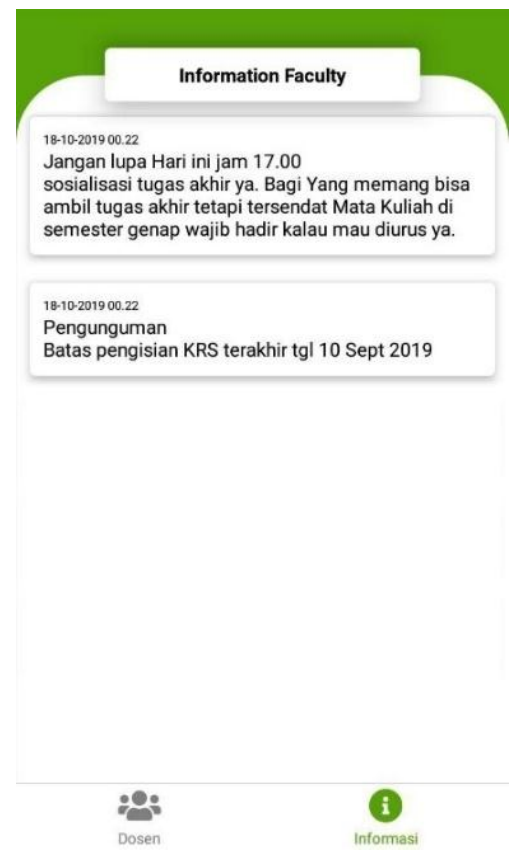

Gambar. 7 Informasi fakultas

Informasi Fakultas yang ditampilkan pada Gambar 7 merupakan tambahan fitur yang diimplementasikan pada aplikasi Smart Indicator Lecturer yang difungsikan untuk menginformasikan berita - berita terkait informasi penting dari Universitas [13].

\section{Pengujian}

Pengujian dilakukan menggunakan blackbox testing pada fitur yang ada untuk mengetahui keberhasilan dari aplikasi yang telah dibangun [14].

TABEL I

PenguJian PADA Alat DAN APLiKasi

\begin{tabular}{|c|c|c|c|}
\hline Fitur & $\begin{array}{l}\text { Hasil yang } \\
\text { diharapkan }\end{array}$ & $\begin{array}{c}\text { Hasil yang } \\
\text { diuji }\end{array}$ & Keterangan \\
\hline $\begin{array}{l}\text { Pendaftaran } \\
\text { Fingerprint }\end{array}$ & $\begin{array}{l}\text { Alat dapat } \\
\text { melakukan } \\
\text { pendaftaran } \\
\text { fingerprint yang } \\
\text { belum terdaftar } \\
\text { dan dipasangkan } \\
\text { id terbaru. }\end{array}$ & $\begin{array}{l}\text { Fingerprint } \\
\text { berhasil } \\
\text { didaftarkan \& } \\
\text { mendapatkan id } \\
\text { berbeda. }\end{array}$ & Berhasil \\
\hline $\begin{array}{c}\text { Scan } \\
\text { Fingerprint }\end{array}$ & $\begin{array}{l}\text { Alat dapat } \\
\text { memindai } \\
\text { fingerprint yang } \\
\text { telah ada pada } \\
\text { database }\end{array}$ & $\begin{array}{l}\text { Alat berhasil } \\
\text { memindai } \\
\text { dengan ditandai } \\
\text { bunyi pada alat } \\
\text { scanner }\end{array}$ & Berhasil \\
\hline $\begin{array}{c}\text { LED } \\
\text { Keberhasilan } \\
\text { Fingerprint }\end{array}$ & $\begin{array}{l}\text { Lampu akan } \\
\text { menyala } \\
\text { berwarna hijau } \\
\text { jika fingerprint } \\
\text { benar dan lampu } \\
\text { akan menyala } \\
\text { berwarna merah } \\
\text { jika fingerprint } \\
\text { tidak dikenali }\end{array}$ & $\begin{array}{l}\text { Lampu berhasil } \\
\text { menyala sesuai } \\
\text { dengan kondisi } \\
\text { fingerprint benar } \\
\text { dan tidak } \\
\text { dikenali }\end{array}$ & Berhasil \\
\hline Bunyi & $\begin{array}{l}\text { Suara akan } \\
\text { berbunyi ketika } \\
\text { data terkirim ke } \\
\text { server pada saat } \\
\text { fingerprint benar }\end{array}$ & $\begin{array}{l}\text { Suara berhasil } \\
\text { terdengar dan } \\
\text { data sampai ke } \\
\text { server }\end{array}$ & Berhasil \\
\hline $\begin{array}{l}\text { Input Data } \\
\text { Dosen }\end{array}$ & $\begin{array}{l}\text { Database } \\
\text { diinputkan data } \\
\text { dosen (berupa id) } \\
\text { dan disinkronkan } \\
\text { pada alat dengan } \\
\text { aplikasi }\end{array}$ & $\begin{array}{l}\text { Data dosen } \\
\text { (berupa id) } \\
\text { berhasil } \\
\text { diinputkan dan } \\
\text { disinkronisasikan } \\
\text { pada alat dengan } \\
\text { aplikasi }\end{array}$ & Berhasil \\
\hline $\begin{array}{l}\text { Indikator } \\
\text { Dosen }\end{array}$ & $\begin{array}{l}\text { Indikator aplikasi } \\
\text { dapat mengubah } \\
\text { status kehadiran } \\
\text { dosen (ditandai } \\
\text { warna merah } \\
\text { maupun hijau) } \\
\text { dengan } \\
\text { melakukan proses } \\
\text { scanning } \\
\text { fingerprint }\end{array}$ & $\begin{array}{l}\text { Indikator pada } \\
\text { aplikasi berhasil } \\
\text { berubah warna } \\
\text { menjadi hijau } \\
\text { jika hadir dan } \\
\text { merah jika tidak } \\
\text { hadir }\end{array}$ & Berhasil \\
\hline $\begin{array}{l}\text { Informasi } \\
\text { Fakultas }\end{array}$ & $\begin{array}{l}\text { Fitur informasi } \\
\text { fakultas akan } \\
\text { menampilkan } \\
\text { informasi terbaru } \\
\text { dengan } \\
\text { diposisikan pada } \\
\text { bagian paling atas }\end{array}$ & $\begin{array}{l}\text { Informasi terbaru } \\
\text { yang ditampilkan } \\
\text { telah berhasil } \\
\text { ditempatkan } \\
\text { pada bagian } \\
\text { teratas dan } \\
\text { menyusul } \\
\text { dengan informasi } \\
\text { yang sebelumnya } \\
\text { telah ada. }\end{array}$ & Berhasil \\
\hline
\end{tabular}


Tabel 1 menampilkan pengujian terhadap alat dan aplikasi yang telah dirancang, dari hasil pengujian tersebut dihasilkan keterangan berhasil sebab hasil pengujian telah sesuai dengan hasil yang diharapkan peneliti.

Adapun pengujian langsung dilakukan dengan menguji pada sidik jari dosen Fakultas Teknologi Komunikasi dan Informatika Universitas Nasional. Proses Sampling dari proses pencocokan citra ditunjukkan pada gambar dibawah ini [15].

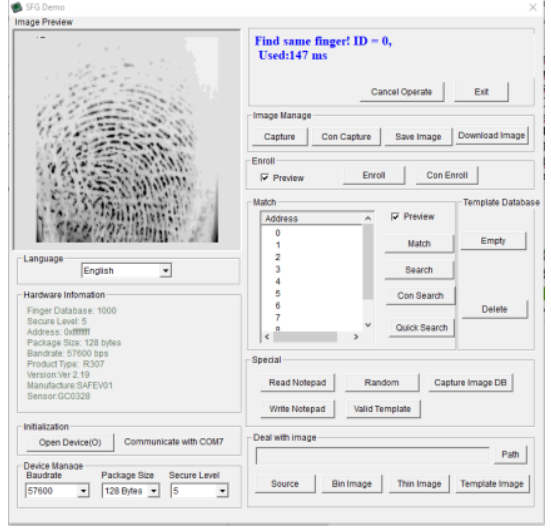

Gambar. 8 Sample scanning fingerprint

Kemudian dilakukan pengujian sebanyak 220 kali dari 11 dosen dengan 2 posisi berbeda, yaitu normal dan miring, masing - masing posisi diujikan sebanyak 10 kali dan menghasilkan grafik yang ditunjukkan oleh Gambar 8 [16].

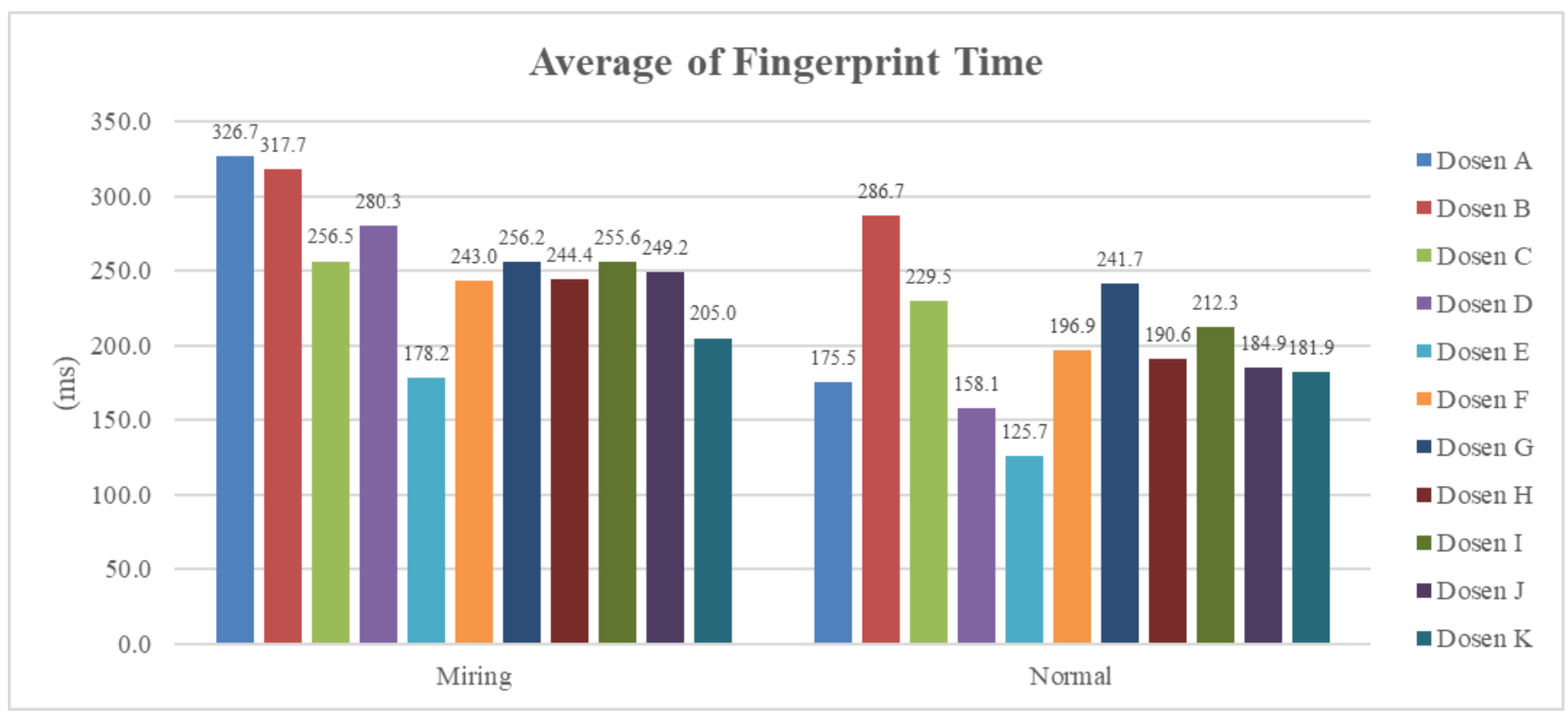

Gambar. 9 Average of fingerprint time

Pada Gambar 9 memperlihatkan rata-rata waktu mengetahui fingerprint dosen dengan satuan milisecond (ms). Pengujian ini mendapatkan hasil tercepat yaitu sebesar $125,7 \mathrm{~ms}$ pada keadaan normal dan terlambat sebesar $326,7 \mathrm{~ms}$ pada keadaan miring. Bagaimana data tersebut mendapatkan rata - rata sebesar $198,5 \mathrm{~ms}$ dalam keadaan scan fingerprint secara normal (jari tegak lurus sesuai dengan sensor), pada keadaan miring (jari miring $90^{\circ}$ ) nilai lebih besar dari keadaan normal mendapatkan rata - rata waktu sebesar 225,7ms dikarenakan pada saat scan jari melebihi dari sensor yang ada. Maka rata-rata yang didapat sebesar $227,1 \mathrm{~ms}$ secara keseluruhan data yang diuji [17].

Keberhasilan pengujian selama proses scanning fingerprint diterangkan pada Gambar 10 dibawah ini [18]. 


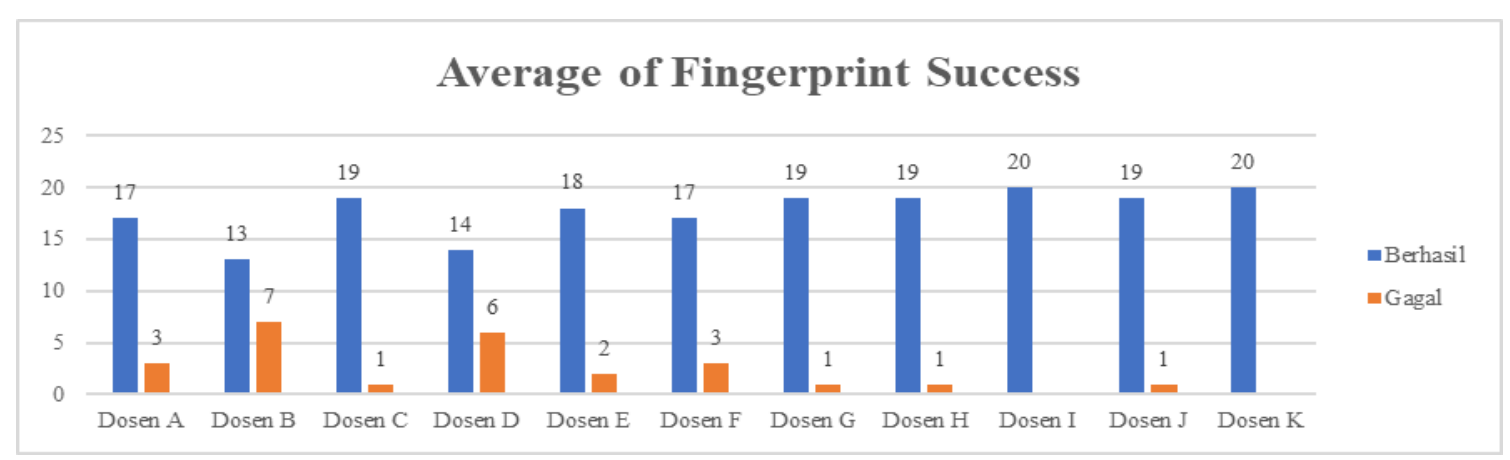

Gambar 10. Average of fingerprint success

Pada Gambar 10 ditunjukkan hasil rata - rata pengujian pengenalan fingerprint dengan database yang ada, berdasarkan hasil tersebut, tingkat keberhasilan rata - rata terbaca sebesar $88,6 \%$ dan rata - rata kegagalan tidak terbaca yaitu $11,4 \%$. Kegagalan pengujian didasari dari tipisnya gerutan yang ada pada masing - masing dosen, semakin tipis gerutan jari akan menyulitkan proses identifikasi.

Pengujian dilakukan dengan skala likert yang digunakan untuk mengukur pendapat user mengenai keberhasilan aplikasi Smart Indicator Lecturer berdasarkan penilaian yang telah ditetapkan oleh peneliti [19]. Pengujian dilakukan dengan menyebarkan kuesioner kepada 30 mahasiswa selaku user dengan menggunakan 5 skala penilaian yaitu nilai 1 untuk Sangat Tidak Setuju (STS), nilai 2 untuk Tidak Setuju (TS), nilai 3 untuk Ragu - Ragu (RG), nilai 4 untuk Setuju (S) dan nilai 5 untuk Sangat Setuju (SS). Adapun nilai interpretasi dikategorikan sebagai berikut:
TABEL II

NILAI INTERPRETAS

\begin{tabular}{|c|l|c|}
\hline Persentase Total & \multicolumn{1}{|c|}{ Interpretasi } & Nilai \\
\hline $80 \%-100 \%$ & Sangat Setuju & 5 \\
\hline $60 \%-79,9 \%$ & Setuju & 4 \\
\hline $40 \%-59,9 \%$ & Ragu - Ragu & 3 \\
\hline $20 \%-39,9 \%$ & Tidak Setuju & 2 \\
\hline $0 \%-19,9 \%$ & Sangat Tidak Setuju & 1 \\
\hline
\end{tabular}

Kuesioner dilakukan dengan mengajukan 9 pertanyaan yang telah disusun peneliti terkait dengan tujuan penelitian, kemudahan akses, tampilan dan fungsionalitas.

Dari total 30 responden yang merupakan mahasiswa Universitas Nasional, didapatkan hasil yang ditunjukkan pada Tabel 3.

TABEL III

KUESIONER MENGGUNAKAN SKALA LIKERT

\begin{tabular}{|c|c|c|c|c|c|c|c|c|c|c|c|c|c|c|}
\hline \multirow{2}{*}{ No } & \multirow{2}{*}{ Pertanyaan } & \multicolumn{5}{|c|}{ Jawaban Responden } & \multicolumn{5}{|c|}{ Nilai Skala Likert } & \multirow{2}{*}{$\begin{array}{l}\text { Total } \\
\text { Nilai }\end{array}$} & \multirow{2}{*}{$\begin{array}{c}\text { Total } \\
(\%)\end{array}$} & \multirow{2}{*}{ Interpretasi } \\
\hline & & STS & TS & RG & $\mathbf{S}$ & SS & STS & TS & RG & $\mathbf{S}$ & SS & & & \\
\hline 1 & $\begin{array}{l}\text { Aplikasi memungkinkan untuk } \\
\text { mengetahui kehadiran dosen }\end{array}$ & 0 & 0 & 6 & 10 & 14 & 0 & 0 & 18 & 40 & 70 & 128 & $85,3 \%$ & Sangat Setuju \\
\hline 2 & $\begin{array}{l}\text { Aplikasi memberikan informasi } \\
\text { fakultas terbaru }\end{array}$ & 0 & 0 & 3 & 15 & 12 & 0 & 0 & 9 & 60 & 60 & 129 & $86 \%$ & Sangat Setuju \\
\hline 3 & $\begin{array}{l}\text { Aplikasi mudah dan nyaman } \\
\text { digunakan }\end{array}$ & 0 & 0 & 0 & 15 & 15 & 0 & 0 & 0 & 60 & 75 & 135 & $90 \%$ & Sangat Setuju \\
\hline 4 & $\begin{array}{l}\text { Aplikasi tidak memakan ruang } \\
\text { penyimpanan }\end{array}$ & 0 & 0 & 2 & 17 & 11 & 0 & 0 & 6 & 68 & 55 & 129 & $86 \%$ & Sangat Setuju \\
\hline 5 & $\begin{array}{l}\text { Aplikasi memiliki fitur yang } \\
\text { sederhana dan mudah dipahami }\end{array}$ & 0 & 0 & 3 & 13 & 14 & 0 & 0 & 9 & 52 & 70 & 131 & $87,3 \%$ & Sangat Setuju \\
\hline 6 & $\begin{array}{l}\text { Aplikasi mempercepat mahasiswa } \\
\text { (user) menerima informasi }\end{array}$ & 0 & 0 & 1 & 9 & 20 & 0 & 0 & 3 & 36 & 100 & 139 & $92,7 \%$ & Sangat Setuju \\
\hline 7 & $\begin{array}{l}\text { Aplikasi membantu mahasiswa (user) } \\
\text { dalam menerima informasi }\end{array}$ & 0 & 0 & 0 & 13 & 17 & 0 & 0 & 0 & 52 & 85 & 137 & $91,3 \%$ & Sangat Setuju \\
\hline 8 & $\begin{array}{l}\text { Aplikasi telah dibuat dengan } \\
\text { kebutuhan yang ditentukan }\end{array}$ & 0 & 2 & 7 & 10 & 11 & 0 & 4 & 21 & 40 & 55 & 120 & $80 \%$ & Sangat Setuju \\
\hline 9 & $\begin{array}{l}\text { Aplikasi memiliki tampilan yang } \\
\text { menarik }\end{array}$ & 0 & 0 & 4 & 16 & 10 & 0 & 0 & 12 & 64 & 50 & 126 & $84 \%$ & Sangat Setuju \\
\hline \multicolumn{13}{|c|}{ Rata - Rata Persentase } & $87 \%$ & Sangat Setuju \\
\hline
\end{tabular}


Tabel 3 menunjukkan rata - rata persentase kelayakan 87\% dengan interpretasi sangat setuju, berdasarkan kuesioner diatas maka dapat dinyatakan bahwa user mudah memahami penggunaan aplikasi.

\section{KESIMPULAN}

Berdasarkan hasil pembahasan diatas, maka dapat disimpulkan sebagai berikut:

1. Sistem yang dirancang merupakan sistem presensi dosen dengan rata - rata waktu yang dibutuhkan yaitu $227,1 \mathrm{~ms}$ dan didapatkan rata - rata keberhasilan terbaca yaitu $88,6 \%$.

2. Dinilai dari hasil kuesioner didapatkan nilai $87 \%$ dengan interpretasi sangat setuju yang mengartikan bahwa user dapat dengan mudah memahami dan mengoperasikan aplikasi yang dirancang.

3. Perancangan aplikasi Smart Indicator Lecturer dinilai berhasil berdasarkan pengujian dari user maupun pengujian sistem.

\section{REFERENSI}

[1] Y. Pratomo, "Google: Ada 2,5 Miliar Perangkat Android yang Aktif Dipakai,” Kompas, 2019. [Online]. Available: https://tekno.kompas.com /read/2019/05/08/13310017/google--ada-25-miliar-perangkat-android-yang-aktif-dipakai.

[2] B. S. R. Purwanti, F. A. Mursyid, and S. D. R. Kusmujianti, "Perancangan Sistem Presensi Merespon Pola Sidik Jari Dari Sensor Fingerprint," vol. 17, no. 2, pp. 129-136, 2018.

[3] S. U. Prini and H. R. Iskandar, "Desain Dan Implementasi Sistem Absensi Mahasiswa Menggunakan Fingerprint Berbasis Mikrokontroler," J. Tek. Media Pengemb. Ilmu dan Apl. Tek., vol. 17, no. 1 , p. $19,2018$.

[4] B. R. P. Utami, I. W. A. Arimbawa, and F. Bimantoro, "Sistem Presensi Siswa berbasis Internet of Things menggunakan Sensor Sidik Jari pada SMK Perhotelan 45 Mataram," J. Teknol. Informasi, Komputer, dan Apl. (JTIKA ), vol. 1, no. 2, pp. 224-232, 2019.

[5] A. Fakih, I. K. Raharjana, and B. Zaman, "Pemanfaatan Teknologi Fingerprint Authentication untuk Otomatisasi Presensi Perkuliahan," $J$ Inf. Syst. Eng. Bus. Intell., vol. 1, no. 2, p. 41, 2015.

[6] D. N. Cahyadi, T. Wahyuningrum, and I. Susanto, "Rancang Bangun Sistem Presensi Mahasiswa Berbasis Fingerprint Client Server," J. Inform. dan Elektron., vol. 6, no. 1, pp. 43-48, 2014.

[7] M. Alhothaily, M. Alradaey, M. Oqbah, and A. El-Kustaban, "Fingerprint Attendance System for Educational Institutes," J. Sci. Technol., vol. 20, no. 1, pp. 34-44, 2015.

[8] B. K. P. Mohamed and C. V. Raghu, "Fingerprint attendance system for classroom needs," 2012 Апnи. IEEE India Conf. INDICON 2012, pp. 433-438, 2012.

[9] K. Annas and I. Fitriati, "Perancangan Aplikasi Absensi Mahasiswa Berbasis Android untuk Dosen STKIP Taman Siswa Bima," pp. 278285, 2019.

[10] S. N. Azizah, "Implementasi Sistem Absensi Pegawai Menggunakan Mac Address Smartphone Dengan Sensor Bluetooth Berbasis Mikrokontroller Arduino," J. Explor. IT, vol. 11, no. 1, pp. 20-28, 2019.

[11] D. Setiawan Putra and A. Fauzijah, "Perancangan Aplikasi Presensi Dosen Realtime Dengan Metode Rapid Application Development (RAD) Menggunakan Fingerprint Berbasis Web,” J. Inform. J. Pengemb. IT, vol. 3, no. 2, pp. 167-171, 2018.

[12] - Gat, "Integrasi Fingerprint System Dengan Real Time Absensi Dosen Berbasis Web (Studi Kasus : STMIK Pontianak)," CogITo Smart J. vol. 2, no. 2, p. 135, 2016.

[13] Habibullah and A. B. Pulungan, "Monitoring Kehadiran Siswa
Menggunakan SMS Gateway Berbasis Arduino," Pros. Semin. Nas. Tek. Elektro FORTEI, no. April, pp. 277-281, 2018.

[14] S. Wibowo and Sarjono, "Analisis dan Perancangan Sistem Informasi Presensi Siswa Berbasis Android Pada SD dan SMP Kanaan Globa School Jambi," J. Manaj. Sist. Inf., vol. 3, no. 2, pp. 1093-1105, 2018.

[15] D. Purnomo and M. Alamsyah, "Perancangan Sistem Presensi Kuliah Berbasis Android," Semin. Nas. Sist. Inf., pp. 1083-1088, 2018.

[16] I. Verdian, "Aplikasi Sistem Absensi Mahasiswa Menggunakan Sidik Jari Pada Universitas Putra Indonesia 'Yptk' Padang," J. KomTekInfo Fak. Ilmu Komput., vol. 2, no. 1, pp. 62-78, 2015.

[17] J. R. K. Putra, "Sistem Absensi Mahasiswa Menggunakan Finger Print U Are U 4500 pada STMIK AMIK RIAU," Jar. Sist. Inf. Robot., vol. 2, no. 01 , pp. $75-80,2018$.

[18] V. O. Wihana and F. Amrullah, "Penerapan Sistem Informasi Presensi Mahasiswa Menggunakan Fingerprint Berbasis Web," J. Comput. Sci. Appl. Informatics, vol. 1, no. 2, 2019.

[19] A. P. Raharjo, A. B. P. Negara, and N. Safriadi, "Sistem Informasi Kehadiran Dosen dan Mahasiswa Menggunakan Sidik Jari pada Program Studi Informatika Universitas Tanjungpura," J. Sist. dan Teknol. Inf., vol. 6, no. 2, p. 76, 2018. 